\title{
Daugiabučių namų atnaujinimas Lietuvoje: problemos ir gyventojų iniciatyva
}

\author{
Anna Lipnevič \\ Lietuvos socialiniu tyrimu centras \\ A. Goštauto g. 11, LT-01108 Vilnius \\ DOI:10.13165/VPA-15-14-2-02
}

\begin{abstract}
Anotacija. Ne tik aprūpinimas būstu, bet ir gyvenamuju namu bei ištisu kvartalu kompleksinis modernizavimas yra svarbus darnaus miestu vystymo, būsto politikos, o kartu ir gerovès valstybès uždavinys. Nors didžioji dalis Lietuvos gyventoju gyvena daugiabučiuose namuose, tačiau tik antrojo Lietuvos nepriklausomybès dešimtmečio viduri galima laikyti dangiabučiu namu atnaujinimo politikos pradžia, o kvartalinès renovacijos užuomazgos pasirodè tik prasidejus trečiajam nepriklausomybès dešimtmečiui. Daugiabučiu namu (toliau - DN) atnaujinimas yra vienas iš svarbiausiu uždaviniu LR Aplinkos ministerijai, tačiau šis procesas dèl ịvairiu priežasčiu nuolat stringa.

DN atnaujinimas Lietuvos mokslininku analizuojamas daugiausia inžineriniu ar ekonominiu aspektu, tačiau trūksta visuminio požiūrio ị ši fenomena. Straipsnyjel apžvelgiama teisès aktu raida, pateikiami apibendrinti DN statistiniai duomenys, kokybinio (16 giluminiu interviu su bendriju pirmininkais, atliktu Vilniaus ir Kauno mieste) ir kiekybinio (Vilniaus ir Kauno bendriju pirmininku anketinès apklausos) šio reiškinio tyrimu duomenu analizés rezultatai.
\end{abstract}

Raktažodžiai: daugiabučių namu atnaujinimo politika, daugiabučiu modernizacija, gyventoju iniciatyva.

Keywords: renovation policy, modernization of apartment buildings, initiative of the population.

1 Straipsnis parengtas pagal Lietuvos mokslo tarybos finansuotą projektą „Būsto politika Lietuvoje: raida, problemos ir pilietinès iniciatyvos“. Projekto numeris LMT SIN-18/2012. 


\section{Ivadas}

Viena iš svarbiausių būsto politikos sričių yra DN atnaujinimas, kuris iki šiol istatyme apibrezžiamas kaip „statybos darbai, kuriais atkuriamos ar pagerinamos pastato ir (ar) jo inžinerinių sistemų fizinès ir energinès savybės ir (ar) kuriais užtikrinamas iš atsinaujinančių energijos šaltinių gaunamos energijos naudojimas“" [14]. Tačiau architektai tvirtina, jog yra ir kitos svarbios su DN atnaujinimu susijusios spręstinos problemos: socialinès, kraštovaizdžio bei transporto [30]. Be to, vis plačiau kalbama ne tik apie pavienių namų, bet apie kvartalų ${ }^{2}$ (kvartalinę, kompleksinę) renovaciją [20; 29], DN atnaujinimas laikomas neatsiejama miestų atnaujinimo politikos dalimi, o darni miestų plètra neatsiejama nuo kompleksinès DN modernizacijos $[8$, p. 564; $12 ; 27 ; 32]$.

DN atnaujinimo fenomenas pasaulyje yra plačiai tyrinejjamas įvairiais aspektais: šilumos taupymo, architektūros, būsto politikos, sprendimų prièmimo procedūrų, darnaus vystymosi ir kt. [6; 9; 10;33, 34]. Pietų Korèjos mokslininkai, atlikę palyginamąją kai kurių Europos šalių renovacijos tikslų ir politikos analizę, išskiria DN renovaciją skatinančios politikos tipus, tačiau analizei pasirinktos tik ekonomiškai stiprios valstybės: Prancūzija, Vokietija, Danija ir Švedija [8]. Ekonomiškai silpnesniu valstybių DN atnaujinimo klausimai daugiausia analizuojami tik tos pačios šalies mokslininkų, o kompleksinių, palyginamųjų šių valstybinių tyrimų beveik nèra. Lietuvoje DN atnaujinimo klausimais yra plačiai diskutuojama tiek politikoje, tiek žiniasklaidoje [24; 26; 28 ir kt.], tačiau mokslininkų dėmesys šiam reiškiniui vis dar nepakankamas. DN atnaujinimas dažniausiai analizuojamas technikos mokslų atstovų, tačiau retai ir fragmentiškai analizuojamas socialinių mokslų tyrèjų. Išimtis - $2014 \mathrm{~m}$. pasirodžiusi mokslo studija [1], kurioje autoriai išsamiai atskleidžia ne tik būsto ir jo modernizavimo politikos raidą, tačiau pateikia DN gyventojų, daugiabučių namų savininkų bendrijų (DNSB) pirmininkų ir būsto politikoje dalyvaujančių reikšmingų asmenų daugiabučių modernizacijos vertinimą.

DN atnaujinimas Lietuvoje dažniausiai tiriamas energetinio efektyvumo aspektu [4; 5; 11]. Net socialinių mokslų atstovų $2014 \mathrm{~m}$. straipsnyje [12] daugiausia kalbama apie energetinę modernizaciją ir energetinį saugumą, tačiau kiti daugiabučių namų modernizuotini elementai nèra plačiai analizuojami, tik užsimenama apie juos. 2012 m. J. Alchimovienès disertacijoje „Daugiabučių namų miestų gyvenamuosiuose rajonuose darnaus atnaujinimo vertinimas" [4] ir tais pačiais metais pasirodžiusioje mokomojoje knyga apie statinių eksploatavimą ir atnaujinimą [35] teigiama, jog pastatų atnaujinimas yra galimybè ne tik sumažinti suvartojamos energijos apimtis, bet kartu užtikrinti kitus darnos principus, kurių pagrindiniai ir lygiaverčiai komponentai - ekologinis, ekonominis ir socialinis“, tačiau autoriai tiria DN būklę, aplinką, atnaujinimo priemones ir kitus techninius dalykus, bando iniciatyvos nèra perspektyvios ilgalaikiu požiūriu, siekiant spręsti daugelị miesto urbanistiniu problemu. $<\ldots>$ Trūkumas vieningos strategijos, kuria bütu siekiama darnios miesto pletros ir efektyvaus energijos panaudojimo“ [27]. 
pritaikyti daugiabučio iki atnaujinimo ir jo atnaujinimo projekto įvertinimą pagal tam tikrus metodus neanalizuodami vykstančių procesų iš pačių DN gyventojų ar namų atstovų pusės [35, p. 96]. Autoriai tvirtina, kad DN atnaujinimas turétų siekti išlaikyti mišrią socialinę struktūrą daugiabučiuose: „Gaunantys didesnes pajamas gyventojai bando išsikelti iš pasenusių kvartalų, kuriuos reikia atnaujinti, dèl tinkamų butų trūkumo. Tokiems rajonams gresia socialinio stabilumo praradimas" [35, p. 188-190]. Svarbu pažymèti, jog pastarajame mokomajame leidinyje pateikiami kitų šalių (Danijos, Vokietijos ir Austrijos) DN atnaujinimo pavyzdžiai, kuriuose minima Vokietijoje taikyta apklausos praktika DN atnaujinimo klausimais, teiraujantis gyventojų nuomonès apie naujoves, pasitenkinimą arba nepasitenkinimą jomis, taip pat kitų šalių modernizavimo patirtis [35, p. 181] - tai pravartu būtų žinoti politikams vystant DN atnaujinimo politiką Lietuvoje.

Kituose mokslo darbuose pateikiami Lietuvos daugiabučių gyvenamųjų namų techninès būklès tyrimo rezultatai [3], DN atnaujinimas analizuojamas darnaus vystymosi koncepcijos pagrindu [2], aptariama Lietuvos urbanizacija ir DN atnaujinimo būtinybè, kadangi didelè Lietuvos visuomenès dalis yra „finansiškai neịgali““ [12, p. 104].

Atlikta mokslinès literatūros analizė leidžia teigti, kad socialinis DN atnaujinimo aspektas yra labai svarbus, tačiau retai analizuojamas Lietuvos mokslo bendruomenèje. Be to, nėra aiški DN modernizacijos politikos raida Lietuvoje. Šiuo tyrimu siekiama atsakyti ị kelis probleminius klausimus: kaip kūrèsi ir vystėsi DN modernizavimo politika Lietuvoje? Kaip šį fenomeną ir jo pasekmes vertina DN gyventojų atstovai? Pagrindiniai tyrimo uždaviniai: 1) atlikti svarbiausių su DN atnaujinimu susijusių Lietuvos teisès aktų apžvalgą ir DN statistikos duomenų analizę, pristatyti jų rezultatus, taip pat 2) kiekybinio (anketinès apklausos) ir kokybinio (interviu) tyrimų rezultatų analizè ir apibendrinimas.

\section{Daugiabučių atnaujinimo politikos raida}

DN atnaujinimo politikos užuomazgų galime atrasti tarp pagrindinių valstybės remtos programos „Būstas“ (1992) nuostatų: užtikrinti esamo butų fondo šiltinimą ir statyti naujus šiltus būstus; pertvarkyti statybos industriją ir statybinių medžiagų pramonę, plèsti termoizoliacinių medžiagų bei konstrukcijų, taip pat šilumos, dujų, vandens suvartojimo apskaitos ir reguliavimo prietaisų gamybą ir ekonomiškai ją skatinti. Tais pačiais $1992 \mathrm{~m}$. prieš minètą programą „Būstas“ buvo patvirtintos naujos statybos normos, pagal kurias pastatams buvo keliami griežtesni šilumos izoliacijos reikalavimai [14]. Nors minèti žingsniai labai svarbūs DN atnaujinimo procesui Lietuvoje, tačiau aktyvios daugiabučių atnaujinimo politikos pradžia galima laikyti tik nepriklausomybès pirmojo dešimtmečio vidurị, kai Lietuvos Respublikos Vyriausybe ir Pasaulio bankas 1996 m. pasirašè sutartị dèl daugiabučiu namu atnaujinimo. Pagal šią sutartị 1996-2003 m. buvo ịgyvendinamas Energijos taupymo būste demonstracinis projektas (toliau - ETBD projektas) 
šilumos punktams ir šildymo sistemoms modernizuoti, langams ir lauko durims keisti, stogams bei sienoms šiltinti ir kt. Programos [18] 8 punkte patikslinta, kad daugiabučiu namu atnaujinimas buvo finansuojamas Pasaulio banko įsteigto apyvartinio fondo lëšomis, o iš LR valstybès biudžeto kompensuota 30 procentų investicijų. Tame pačiame nutarimo punkte pažymèta, kad pagal šị projektą iš dalies atnaujinta (be sienų šiltinimo) daugiau kaip 700 daugiabučių namų, investuota per 70 mln. litų, o šiluminès energijos sąnaudos šiuose pastatuose sumažintos apie ketvirtadali [18].

Svarbiausi su Lietuvos DN atnaujinimo politika susiję teisès aktai su trumpu jų aprašymu pateikiami 1 lentelèje. Lietuvoje būsto, o kartu ir DN atnaujinimo, politika yra kuriama gana vangiai: nors LRV 2001-2004 m. programoje buvo numatyta parengti būsto plètros strategiją dar $2003 \mathrm{~m}$. I ketvirtyje, Lietuvos būsto strategija buvo priimta tik $2004 \mathrm{~m}$. sausio $21 \mathrm{~d}$., o jos nuostatų igyvendinimo laikotarpis nurodomas iki 2020 metų.

\section{1 lentelè. Svarbiausi valstybès institucijų teisiniai žingsniai siekiant atnaujinti daugiabučius namus}

\begin{tabular}{|c|c|c|}
\hline Metai & Dokumento pavadinimas & Naujovè \\
\hline 1992 & $\begin{array}{l}\text { Patvirtinti nauji statybu reikalavimai } \\
\text { Statybos ir urbanistikos ministerijos } \\
\text { 1992-05-20 isakymas Nr. 97 „Dèl } \\
\text { statybos normų RSN 143-92 „Pastatų } \\
\text { atitvaru šiluminè technika“ tvirtinimo“ } \\
\text { (Žin., 1994, Nr. 22-367; 1995, Nr. 95- } \\
\text { 2143) [13] }\end{array}$ & $\begin{array}{l}\text { Nustatyti nauji normatyviniai reika- } \\
\text { lavimai pastatų atitvarų šiluminiam } \\
\text { laidumui, šildymo ir vẻdinimo siste- } \\
\text { moms }\end{array}$ \\
\hline 1992 & $\begin{array}{l}\text { Nauja paramos programa } \\
\text { Lietuvos Respublikos Vyriausybès } \\
1992 \text { m. liepos } 17 \text { d. nutarimas Nr. } 562 \\
\text { „Dėl valstybés remiamos programos } \\
\text { „Būstas“ (Žin., 1992, Nr. 27-791) }\end{array}$ & $\begin{array}{l}\text { Vienas iš tikslų buvo energijos taupymo } \\
\text { pastatuose skatinimas }\end{array}$ \\
\hline 1996 & $\begin{array}{l}\text { Energijos taupymo būste projektas } \\
\text { LRS ir Pasaulio banko pasirašyta } \\
\text { sutartis dèl energijos taupymo būste } \\
\text { demonstracinio projekto [17] }\end{array}$ & $\begin{array}{l}\text { 1996-2003 m. atnaujinta (be sienų šilti- } \\
\text { nimo) daugiau kaip } 700 \text { daugiabučių } \\
\text { namų }\end{array}$ \\
\hline 1999 & $\begin{array}{l}\text { Pakeisti statybu reikalavimai } \\
\text { LR aplinkos ministro 1999-04-29 } \\
\text { isakymas Nr. } 117 \text { „Dèl statybos tech- } \\
\text { ninių reglamentų patvirtinimo“ }\end{array}$ & $\begin{array}{l}\text { Panaikino } 19920520 \text { ịsakymą Nr. } 97 . \\
\text { Isakymo } 1 \text { priedas: statybos techninių } \\
\text { reikalavimų reglamentas STR } \\
\text { 2.05.01:1999 „Pastatu atitvarų šiluminè } \\
\text { technika“. Jis nustato šiluminius tech- } \\
\text { ninius reikalavimus gyvenamųjų, viešo- } \\
\text { sios paskirties ir pramonès pastatų } \\
\text { atitvarams projektuoti. Reglamentas } \\
\text { taikomas projektuojant naujus ir re- } \\
\text { konstruojamus pastatus }\end{array}$ \\
\hline
\end{tabular}




\begin{tabular}{|c|c|c|}
\hline $2004 \mathrm{~m}$ & $\begin{array}{l}\text { Patvirtinta Lietuvos būsto strategija } \\
\text { LRV 2004-01-21 d. nutarimas Nr. } 60 \\
\text { „Dèl Lietuvos būsto strategijos patvir- } \\
\text { tinimo“ }\end{array}$ & $\begin{array}{l}\text { Vienas svarbiausių Strategijos tikslų - } \\
\text { užtikrinti tinkamą būsto priežiūrą, } \\
\text { atnaujinimą ir modernizavimą mažinant } \\
\text { energijos sąnaudas. Laikotarpis - iki } \\
2020 \mathrm{~m} \text {. }\end{array}$ \\
\hline 2004 & $\begin{array}{l}\text { Daugiabučiu namu modernizavimo } \\
\text { programa } \\
\text { LRV 2004-09-23 nutarimas Nr. } 1213 \\
\text { „Dėl Daugiabučių namų moderni- } \\
\text { zavimo finansavimo programos“. Isi- } \\
\text { galiojo 2004-09-26 (Žin., 2004, Nr.143- } \\
\text { 5232) [16]. }\end{array}$ & $\begin{array}{l}\text { Svarbiausias šios Programos tikslas - } \\
\text { padéti daugiabučiu namų savininkams } \\
\text { modernizuoti daugiabučius namus, } \\
\text { didinti energijos vartojimo efektyvumą, } \\
\text { mažinti šildymo išlaidas ir užtikrinti } \\
\text { mažas pajamas gaunančioms šeimoms } \\
\text { (vieniems gyvenantiems asmenims) } \\
\text { palankias sąlygas modernizuoti dau- } \\
\text { giabučius namus, kuriuose jos (jie) gy- } \\
\text { vena }\end{array}$ \\
\hline 2005 & $\begin{array}{l}\text { Valstybès paramos būstui isigyti ar } \\
\text { išsinuomoti ịstatymo pavadinimo } \\
\text { pakeitimas } \\
\text { LRS } 2005 \text { m. kovo } 24 \text { d. įstatymas Nr. } \\
\text { X-143 (Žin., 2005, Nr. 47-1554) [14] }\end{array}$ & $\begin{array}{l}\text { Naujas pavadinimas Valstybės paramos } \\
\text { būstui įsigyti ar išsinuomoti bei dau- } \\
\text { giabučiams namams modernizuoti } \\
\text { ịstatymas. Siame ịstatyme nustatyti } \\
\text { valstybės paramos daugiabučiams na- } \\
\text { mams modernizuoti teikimo sąlygos ir } \\
\text { būdai bei finansavimas. } \\
\text { Papildytas apibrěžimu: „,daugiabučio } \\
\text { namo modernizavimas - statybos dar- } \\
\text { bai, kuriais iš dalies arba visiškai atnau- } \\
\text { jinamos ir pagerinamos pastato ir (ar) jo } \\
\text { inžinerinių sistemų fizinès ir energinės } \\
\text { savybės“ }\end{array}$ \\
\hline 2013 & $\begin{array}{l}\text { Pakeistas daugiabučiu namu finansa- } \\
\text { vimo modelis } \\
\text { LRS 2013m. sausio } 17 \text { d. Nr. XII-149 } \\
\text { Valstybès paramos būstui įsigyti ar } \\
\text { išsinuomoti ir daugiabučiams namams } \\
\text { atnaujinti (modernizuoti) ịstatymo 13, } \\
14 \text { ir } 15 \text { straipsnių pakeitimo ịstatymas } \\
\text { Itsigaliojo 2013-03-01 (4 straipsnio } 2 \\
\text { dalis įsigalioja 2013-01-26) [15] }\end{array}$ & $\begin{array}{l}\text { Masinio daugiabučiu namų moder- } \\
\text { nizavimo, dar vadinamo „kvartaline } \\
\text { renovacija“, pradžia [21]. } \\
\text { Patiems gyventojams nebūtina imti } \\
\text { paskolos iš bankų, tai gali daryti } \\
\text { savivaldybių įmonės, o paskolos bus grą- } \\
\text { žinamos iš sutaupytu šildymo pinigų. } \\
\text { Savivaldybès atrenka energetiškai } \\
\text { neefektyviausius namus. 100 proc. } \\
\text { padengiamos investicinio projekto lěšos }\end{array}$ \\
\hline
\end{tabular}

Tuos pačius $2004 \mathrm{~m}$. galima laikyti aktyvios DN atnaujinimo politikos pradžia. Nuo 2013 m. pasikeite DN modernizavimo finansavimo tvarka, ją dar per anksti vertinti, kadangi dar nèra nei vieno pagal naują tvarką atnaujinto daugiabučio namo.

Kvartalinė, arba kompleksinė, renovacija. Lietuvos daugiabučių modernizacijos modelis, nors ir iš lèto, tačiau pereina ị kitą etapą - nuo fragmentiško paskirų namų atnaujinimo prie kompleksinès - kvartalinès - modernizacijos, kuri apima ne tik pavienių daugiabučių namų energetinio efektyvumo didinimą (apšil- 
tinimą, šilumos punkto atnaujinimą), bet ir gyvenamosios aplinkos kokybės gerinimą, infrastruktūros objektų sutvarkymą, šilumos gamybos ir tiekimo sistemų modernizavimą, visuomeninès paskirties pastatų renovavimą [20]. Kompleksiné renovacija yra darnios miesto plètros ir darnaus būsto (at)kūrimo priemonè. Darnus būstas - tai ne tik pastogè, - tai aplinka, kurioje jis yra, įvairių galimybių - išlaikymo, poilsio, susisiekimo ir kt. - už(si)tikrinimas. Darnaus būsto (at)kūrimas neatsiejamas nuo kvartalinès, arba kompleksinès, renovacijos. Pagrindiniai tokio būsto (at)kūrimo etapai turètų būti / yra: kompleksinis (kvartalinis) projektavimas $\rightarrow$ projektavimas $\rightarrow$ statyba $\rightarrow$ renovacija $\rightarrow$ kompleksinè renovacija.

Realūs kompleksinio atnaujinimo veiksmai Lietuvoje pradèti tik $2013 \mathrm{~m}$. pakeitus daugiabučių namų finansavimo modelị. Iki tol vyko tik kelių miestų bandymai (Birštono ir Palangos), kuriais buvo siekiama igyvendinti $2010 \mathrm{~m}$. prasidejjusi tarptautinį demonstracinị „ECO-life“ projektą (http://www.ecolife-project.eu/) kartu su dar dviejomis valstybèmis - Belgija ir Danija. Šio projekto tikslas - pademonstruoti novatoriškas integruotas energijos koncepcijas transformuojant miestus ị CO2 neutralias bendruomenes. Projektas prasidejjo $2010 \mathrm{~m}$. sausio mėnesị ir baigsis 2016 m. sausio mėnesị, tačiau Lietuvos miestams sunkiai sekèsi pralaužti „tipinès renovacijos“ viziją, ir nuspręsta pasitraukti iš šio perspektyvaus bandomojo projekto, vadinamu ,,nefinišavusiu kompleksinès modernizacijos pavyzdžiu“ [25].

Apibendrinant galima teigti, jog Lietuvos daugiabučių namų atnaujinimo politika, kuri pradèta kurti dar prieš du dešimtmečius, nèra iki galo susiformavusi ir yra nuolat tobulinama, keičiamas finansavimo modelis. Svarbu pabrèžti, jog iki šiol svarbiausiu DN atnaujinimo politikos prioritetu Lietuvoje išlieka DN energijos vartojimo efektyvumo didinimas.

\section{Lietuvos daugiabučių ir jų atnaujinimo statistika}

Lietuvoje 2013 m. sausio 1 d. buvo 37463 daugiabučiai namai [35]. $2011 \mathrm{~m}$. gyventojų ir būstų surašymo duomenimis, 59,8 proc. gyvena daugiabučiuose namuose: 81,2 proc. jų gyvena miestų DN, ir tik 17,1 proc. - kaimų DN [31]. Daugiabučių namų atnaujinimo (modernizavimo) programoje (2004, toliau - Programa) numatyta skatinti daugiabučių namų, pastatytų pagal galiojusius iki 1993 m. statybos techninius normatyvus, atnaujinimą [17]. Nacionalinès žemès tarnybos prie ŽŪM (toliau - NŽT) duomenimis, Lietuvoje iki $1990 \mathrm{~m}$. pabaigos pastatytų namų yra net 91,3 proc., t. y. 9 iš dešimties namų teoriškai atitinka minètą kriterijų. Svarbu pažymèti, kad apie trečdalis daugiabučių keturiose - Kauno, Klaipèdos, Tauragès ir Vilniaus - apskrityse yra pastatyti iki 1940 m. [27]. Šių duomenų pagrindu galima teigti, kad Lietuvos daugiabučių gyvenamasis fondas yra gana senas.

Nors jau ịsibègèjo 3 nepriklausomybès dešimtmetis, tačiau ịvairių šaltinių duomenys rodo, jog atnaujintų daugiabučių kol kas yra tik iki 1 proc. Svarbu pažymèti, jog yra duomenu gavimo problema - Lietuvoje nèra vieningos DN atnaujinimo statistikos, sudètinga gauti duomenis, kur ir kokie buvo atnaujinimo dar- 
bai, kokia jų piniginè vertė. Kalbant apie anksčiau prasidejjusi DN atnaujinimą, iki $2004 \mathrm{~m}$. pagal DN atnaujinimo programas buvo iš dalies ar visiškai renovuoti tik apie 700 daugiabučių [18]. Kito šaltinio - Lietuvos šilumos tiekejų asociacijos duomenimis, nuo 1998 iki 2014 m. spalio mèn. visiškai atnaujinti / atnaujinami yra apie 664 daugiabučiai, iš dalies - 903 (tačiau skelbiami tik 317-os namų atnaujinimo metai) (2 lentelè).

2 lentele. Daugiabučių namų atnaujinimo (modernizavimo) statistika 1998-2014 m.

\begin{tabular}{|c|c|c|c|c|c|}
\hline Metai & $\begin{array}{c}\text { Visiškai } \\
\text { modernizuoti } \\
\text { namai }\end{array}$ & $\begin{array}{c}\text { Iš dalies } \\
\text { modernizuoti } \\
\text { namai }\end{array}$ & Metai & $\begin{array}{c}\text { Visiškai } \\
\text { modernizuoti } \\
\text { namai }\end{array}$ & $\begin{array}{c}\text { Iš dalies } \\
\text { modernizuoti } \\
\text { namai }\end{array}$ \\
\hline $\mathbf{1 9 9 8}$ & 0 & 2 & $\mathbf{2 0 0 7}$ & 35 & 70 \\
\hline $\mathbf{1 9 9 9}$ & 0 & 1 & $\mathbf{2 0 0 8}$ & 66 & 37 \\
\hline $\mathbf{2 0 0 0}$ & 3 & 0 & $\mathbf{2 0 0 9}$ & 70 & 45 \\
\hline $\mathbf{2 0 0 1}$ & 0 & 1 & $\mathbf{2 0 1 0}$ & 90 & 43 \\
\hline $\mathbf{2 0 0 2}$ & 0 & 2 & $\mathbf{2 0 1 1}$ & 91 & 10 \\
\hline $\mathbf{2 0 0 3}$ & 0 & 0 & $\mathbf{2 0 1 2}$ & 74 & 2 \\
\hline $\mathbf{2 0 0 4}$ & 0 & 1 & $\mathbf{2 0 1 3}$ & 59 & 17 \\
\hline $\mathbf{2 0 0 5}$ & 2 & 9 & $\mathbf{2 0 1 4}$ & $125(26$ vyksta) & 30 \\
\hline $\mathbf{2 0 0 6}$ & 23 & 47 & VISO & $\mathbf{6 6 4}$ & $\mathbf{3 1 7}$ \\
\hline
\end{tabular}

Šaltinis: parengta pagal Lietuvos šilumos tiekèjų asociacijos duomenis 2014 m. [19]

Šie duomenys rodo, kad aktyvesnis DN atnaujinimas prasidejo tik $2006 \mathrm{~m}$. ir iki $2010 \mathrm{~m}$. stabiliai po truputị plètèsi. Tą, be abejo, paskatino prièmus Būsto strategiją LR teisinëje bazejje patvirtintas DN modernizavimo mechanizmas [17].

Nuo $2013 \mathrm{~m}$. kovo 1d. ėmus taikyti naujaji DN atnaujinimo finansavimo modeli [16], pirmajame etape pagal naują finansavimo tvarką, planuota renovuoti 836 namus, o antrajame - net dvigubai daugiau - 1680 namus [23; 7]. Šie skaičiai rodo ne tik augantị savivaldybių, bet ir gyventojų aktyvumą, kadangi buvo atsižvelgiama i galimą gyventojų pritarimą.

$2014 \mathrm{~m}$. pasirode pirmasis LR aplinkos ministerijos mėginimas susistemintai pateikti naujojo DN modernizavimo etapo, prasidejjusio 2013 m., statistiką (http:// atnaujinkbusta.lt/). Teigiama, jog nuo $2005 \mathrm{~m}$. iki $2012 \mathrm{~m}$. imtinai yra atnaujinta 479 daugiabučiai namai. Žiniatinklyje pateikiami duomenys pagal savivaldybes: 2014 $\mathrm{m}$. spalio mėnesio pabaigoje parengtų daugiabučių namų modernizacijos investicinių planų buvo beveik visose Lietuvos savivaldybėse (1 pav.), iš viso parengta 2584 planai. Daugiausia projektų buvo parengta didžiųjų miestų savivaldybėse Vilniaus, Kauno ir Klaipėdos. Net jei projektai yra parengti, jie negali būti pradèti be gyventoju pritarimo. $2014 \mathrm{~m}$. spalio $17 \mathrm{~d}$. duomenimis, kol kas investiciniams 
planams pritaré tik 1528 (60 proc.) renovacijai atrinktų namų gyventojai, tačiau savivaldybès ženkliai skiriasi pagal ši rodikli (2 pav.).

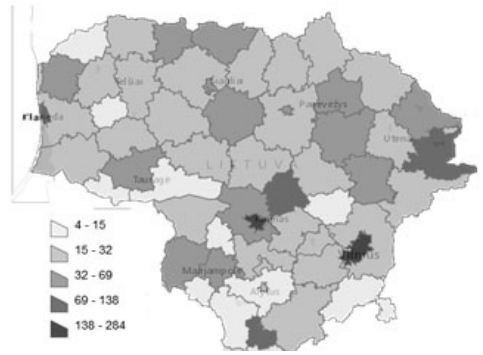

1 pav. Parengti investicijų planai, vnt. $2014 \mathrm{~m}$. spalis [22]

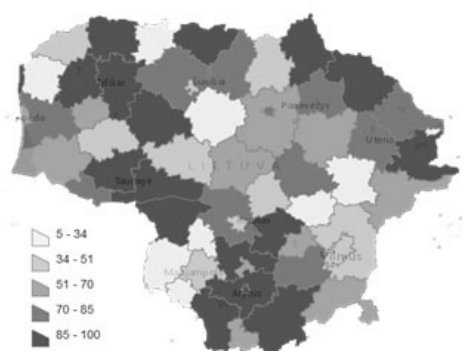

2 pav. Gyventojų pritarimas projektams, proc. $2014 \mathrm{~m}$. spalis [22]

LR aplinkos ministerijos duomenimis, iki $2014 \mathrm{~m}$. spalio $17 \mathrm{~d}$. pagal naują progamą renovuoti tik 63 namai, nors statybos darbai yra pradeti 721-ame name (3 pav.).

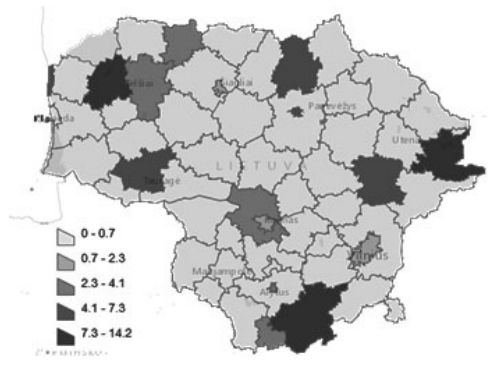

3 pav. Renovacijos proceso pabaiga, proc. 2014 m. spalis [22]

Apibendrinus skelbiamų statistinių duomenų analizès rezultatus, DN modernizacijos Lietuvoje dar kol kas negalime vadinti masine, kadangi iki $2014 \mathrm{~m}$. vidurio tebuvo atnaujinta mažiau negu 1 proc. pagal iki $1993 \mathrm{~m}$. galiojusius statybos reikalavimus pastatytų namų. Daugiabučių atnaujinimas kiek aktyvesnis didžiuosiuose miestuose, tačiau mažuose miesteliuose jis, galima sakyti, beveik nevyksta.

\section{DN atnaujinimas: anketinės apklausos rezultatai}

Kiekybinis tyrimas - anketinè apklausa - padejo nustatyti, kaip ir kokiomis lěšomis vyksta / vyko DN atnaujinimas Vilniaus ir Kauno miestuose. Kiekybiniai tyrimo duomenys buvo renkami 2013 m. kovo-gegužès mèn. naudojant klausimy- 
ną. Apklausos anketa buvo platinama bendrijų pirmininkams Vilniaus ir Kauno miestuose elektroniniu būdu bei skambinant telefonu. Buvo užpildytos 224 anketos: Vilniuje - 154, Kaune - 70 anketos. Klausimyne viena iš dalių buvo 9 tiesiogiai su renovacija susiję klausimai. Kiekybiniai duomenys buvo apdorojami SPSS programa.

Tyrimo metu 13,8 proc. apklaustųų atsake, jog jų DN yra atnaujintas (renovuotas), 73,7 proc. patvirtino, jog jų name nèra atlikto namo atnaujinimo.

Pagrindinès priežastys, dèl kurių senas (pastatytas pagal iki $1993 \mathrm{~m}$. galiojusius reikalavimus) namas nėra renovuotas, respondentai dažniausiai minejjo gyventojų pasyvumą ir priešinimąsi, pinigų trūkumą, paveldosaugos reikalavimus, per ilgą atsipirkimo laikotarpị, kompetentingų specialistų trūkumą, per menką valstybès paramą ir $\mathrm{kt}$.

Tyrimo metu 29 proc. pirmininkų pažymejjo, jog ateityje dar planuoja dalyvauti DN atnaujinimo programoje, o 8 proc. nurode, jog DN atnaujinimas jau atliekamas arba atliktas. Tyrimo duomenys rodo, jog dažniausiai daugiabučiuose namuose yra atnaujintas stogas, šilumos punktas, suremontuota laiptiné, pakeisti langai (4 lentelè).

4 lentele. Atlikti DN atnaujinimo darbai (proc., atsakė 79,5 proc.)

\begin{tabular}{|c|l|c|c|}
\hline & \multicolumn{1}{|c|}{ Darbų rūšis } & Taip & Ne \\
\hline 1. & Pakeisti langai & 48,9 & 51,1 \\
\hline 2. & Pakeisti radiatoriai & 8,4 & 91,6 \\
\hline 3. & Pakeistas vamzdynas & 34,3 & 65,7 \\
\hline 4. & $\begin{array}{l}\text { Pakeista elektros } \\
\text { instaliacija }\end{array}$ & 23,6 & 76,4 \\
\hline 5. & $\begin{array}{l}\text { Apšiltintos šoninės } \\
\text { namo sienos }\end{array}$ & 8,4 & 91,6 \\
\hline 6. & Pakeistas namo stogas & 60,7 & 39,3 \\
\hline 7. & $\begin{array}{l}\text { Ptnaujintas šilumos } \\
\text { punktas }\end{array}$ & 58,4 & 41,6 \\
\hline 8. & $\begin{array}{l}\text { Suremontuota namo } \\
\text { laiptine }\end{array}$ & 61,2 & 38,8 \\
\hline 9. & Kita & 38,2 & 61,8 \\
\hline
\end{tabular}

Daugiau negu pusė apklaustųjų tvirtino, jog buvo pakeistas namo stogas, atnaujintas šilumos punktas ir suremontuota laiptinè. Beveik pusė atsakiusių į klausimą pirmininkų teigé, jog jų name yra pakeisti ir langai. Radiatoriai keičiami rečiausiai, greičiausiai tik namui dalyvaujant DN atnaujinimo programoje. Panaši situacija yra ir su namo sienų apšiltinimu. 
Kas apskritai finansuoja / finansavo DN atnaujinimo darbus, yra nurodyta 5 lentelèje. Beveik 28 proc. atsakiusių pažymėjo, jog DN modernizacija atliekama / buvo atlikta vien gyventojų lèšomis.

\section{5 lentelè. Kokiomis lèšomis buvo atlikta / atliekama namo renovacija? (atsakè 17,9 proc.)}

\begin{tabular}{|l|c|}
\hline & Proc. \\
\hline Vien daugiabučio namo gyventojų lěšomis & 27,5 \\
\hline $\begin{array}{l}\text { Dalyvaujant daugiabučių namų renovacijos programoje, kai } \\
\text { 50 proc. renovavimo kaštų padengė savivaldybė, o kitą } 50 \\
\text { proc. - namo gyventojai }\end{array}$ & 25,0 \\
\hline $\begin{array}{l}\text { Dalyvaujant daugiabučių namų renovacijos programoje, kai } \\
\text { 100 proc. dokumentų rengimo bei 15-30 proc. renovavimo } \\
\text { kaštų padengè savivaldybè, o kitus 75 proc. - namo } \\
\text { gyventojai }\end{array}$ & 10,0 \\
\hline Kita & 35,0 \\
\hline Neatsakė & 2,5 \\
\hline Iš viso & $\mathbf{1 0 0 , 0}$ \\
\hline
\end{tabular}

Respondentai nurodė pagrindines problemas, su kuriomis susidūrė atliekant / rengiantis atlikti renovaciją - tai gyventojų pasipriešinimas, ilgas ir vangus dokumentų rengimo procesas, konsultacinès pagalbos trūkumas, vis keičiama parama ir tvarka, per didelè atsakomybė pirmininkui, nepasitikẻjimas statybos įmonèmis, sunkumai su pensinio amžiaus gyventojais, nepasitikejjimas bankais dèl jų griūties bei kt. Nors didele dalis atsakiusių renovacijos rezultatu yra patenkinti, dalis respondentų minèjo, jog jų netenkina atliktų darbų kokybė, kai kuriais atvejais pasitaikè net vagysčių.

Anketinès apklausos metu respondentai nurodè, kokios, jų nuomone, priežastys gali paspartinti DN atnaujinimą. Kaip svarbiausius skatinančius veiksnius respondentai nurodẻ didesnį ir lankstesnị finansavimą iš savivaldybẻs lèšų bei mažesnius mokesčius už šildymą. Apie 70 proc. respondentų nelabai tiki ịstatymais įteisintos privalomos renovacijos dideliu skatinančiu poveikiu (6 lentelè). Respondentai pažymejjo, jog svarbu yra užtikrinti atliekamų darbų kokybę, Nemažai pirmininkų minèjo, jog panaikinus kompensacijas už šildymą, renovacijos procesas tikrai įsibègètų. Buvo siūlomas ir kitas būdas - eliminuoti iš sprendimų prièmimo žmones, kurie gauna kompensaciją už šildymą. Dar buvo pažymèta, jog „,geriausia butų griauti daugiabučius ir statyti naujus, kadangi renovacija per brangiai kainuoja“". Kiti nurodè, jog turi būti skiriama dèmesio ne tik išorei, bet ir vidinèms sistemoms atnaujinti. 
6 lentelè. Priežastys, kurios galètų skatinti / skatina daugiabučių namų renovaciją

\begin{tabular}{|l|c|c|c|}
\hline & Taip & Ne & Nežino \\
\hline Tiesioginis teigiamas pavyzdys & 39,3 & 53,1 & 7,6 \\
\hline Mažesni mokesčiai už šildymą & 55,4 & 37,1 & 7,6 \\
\hline Padidėjęs šildymo efektyvumas & 41,5 & 50,9 & 7,6 \\
\hline Pagerėjęs estetinis namo vaizdas & 35,3 & 57,1 & 7,6 \\
\hline Patrauklesnė ir saugesnė gyvenamoji aplinka & 28,1 & 64,3 & 7,6 \\
\hline Noras pakelti savo būsto vertę & 21,9 & 70,5 & 7,6 \\
\hline Didesnis ir lankstesnis finansavimas iš savivaldybės lèšų & 57,6 & 34,8 & 7,6 \\
\hline Aiškūs ir ilgalaikiai įstatymai & 44,2 & 48,2 & 7,6 \\
\hline Informacijos apie renovacijos programas sklaida & 21,9 & 70,5 & 7,6 \\
\hline İstatymais ịteisinta privaloma renovacija & 23,7 & 68,8 & 7,6 \\
\hline Kita & 22,8 & 69,6 & 7,6 \\
\hline
\end{tabular}

Kiekybinio tyrimo duomenys buvo papildyti kokybinio tyrimo duomenimis. Pastarieji parodè, kaip vyksta / vyko DN atnaujinimas, kokios priežastys skatina ar stabdo/è ši procesą.

\section{DN atnaujinimo problemos Lietuvoje: kokybinio tyrimo duomenų apibendrinimas}

Svarbiausias su DN atnaujinimu susijusias problemas ir šio proceso pasekmes padejo išryškinti atlikto kokybinio tyrimo (interviu) duomenys. Minètas tyrimas buvo atliekamas $2013 \mathrm{~m}$. sausio-rugpjūčio mèn. Tyrimo metu buvo atlikta 8 interviu su Vilniaus ir 8 interviu su Kauno m. DNSB pirmininkais bei 3 interviu su būsto valdymo ir priežiūros ekspertais (iš viso $\mathrm{n}=19$ ). Apklausti 12 pirmininkų, kurių valdomi namai (daugiau nei 12 namų) yra visiškai ar iš dalies atnaujinti.

DN atnaujinimo procesas informantų apibūdinamas ịvairiausiais epitetais: „kryžiaus keliai“, „didele loterija“, „pinigų plovimas“ ir kt. Tai sudètingas ne tik ekonominis ir inžinerinis, bet kartu ir socialinis fenomenas. Svarbu pažymèti, jok kokybinio tyrimo duomenys patvirtina nemažą dali kiekybinio tyrimo metu respondentų nurodytų problemų. Apibendrinant kiekybinio ir kokybinio DN atnaujinimo tyrimų analizès rezultatus galima išskirti $\mathrm{DN}$ atnaujinimo procesą spartinančius ir lètinančius faktorius (7 lentelè). Tiek Kauno, tiek Vilniaus miesto informantai kaip pagrindinį trukdi pradèti namo atnaujinimą pabrěžia gyventojų pasyvumą. İtraukiant gyventojus, kad jie nebūtų pasyvūs savo namo renovavimo klausimais, informantai ypač pabréžia vadovo vaidmenị.

Tyrimo metu informantai ịvardijo ir kitas su DN atnaujinimo procesu susijusias problemas: gerų įmonių trūkumas, įmonių nestabilumas, korupcija, darbininkų problema, informacijos iš savivaldybių trūkumas ir jų nenoras bendrauti (esant 
privalomai renovacijai), neigiama informacija apie DN atnaujinimą, nevisiškas DN atnaujinimas, DN atnaujinimo modelių keitimas ir kt.

\section{7 lentele. DN atnaujinimo proceso veiksniai}

\begin{tabular}{|c|c|}
\hline Skatinantys veiksniai & Stabdantys veiksniai \\
\hline 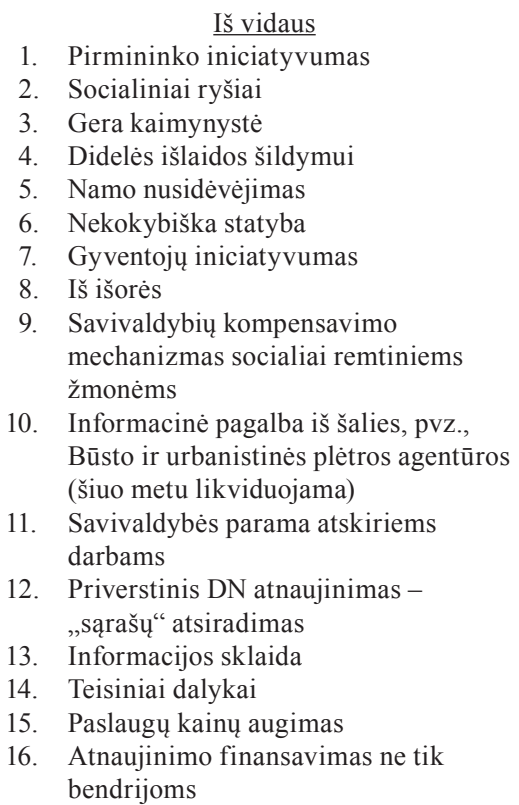 & 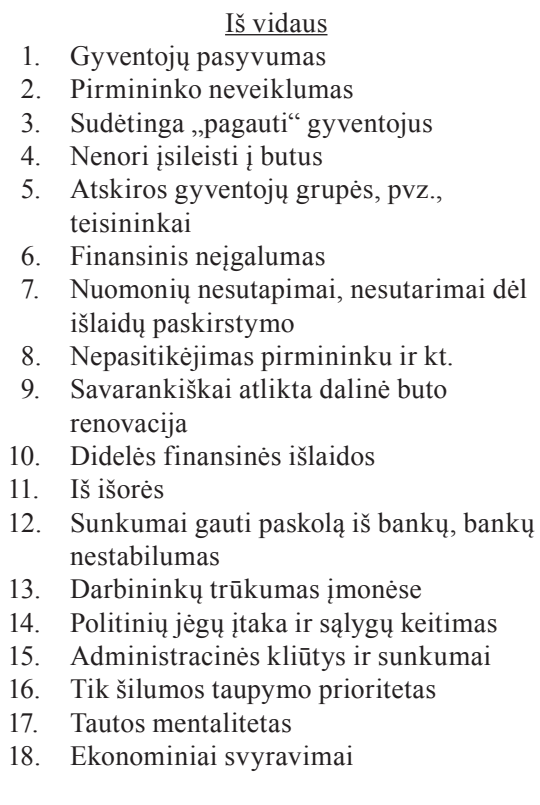 \\
\hline
\end{tabular}

Šaltinis: sudaryta autorès

Teigiamos DN atnaujinimo pasekmès. Techniniu aspektu DN bendrijų informantai vieningai teigia, jog renovavus namą išauga jo vertè, sumažeja išlaidos būsto išlaikymui. Vertinant socialinius dalykus galima pastebėti, jog renovavimo procesas suartina kaimynus. Renovacijai pasibaigus, dalis gyventojų neslepia emocijų, atsidèkoja pirmininkui. Neabejotinai atnaujintais daugiabučiais namais, informantų teigimu, gyventojai yra patenkinti, nepaisant vykusio atnaujinimo proceso nesklandumų, tarpusavio nesutarimų ir pan.

Neigiamos DN atnaujinimo pasekmès. Svarbiausia atnaujintų DN problema Lietuvoje yra ta, jog dažniausiai DN namai atnaujinami tik iš dalies, atsižvelgiant tik į šilumos taupymo prioritetą, nors dažnai reikalinga visiška namo modernizacija. Energetiniu aspektu, diegiant autonomines šildymo sistemas, ne visada atsižvelgiama ị radiatorių skaičiaus butuose nesutapimus. Be to, atliktų DN atnaujinimo darbų kokybè ne visuomet būna gera. 
Informantai tyrimo metu išsake ne tik DN atnaujinimo problemas, bet taip pat ir naudingas įžvalgas ir patarimus planuojantiems atnaujinti DN: pabrèžè griežtą įmonių atranką ne tik kainos aspektu, techninio prižiūrètojo kruopštų atrinkimą, medžiagų ilgaamžiškumo klausimus, ilgalaikio bendravimo su gyventojais svarbą.

Kaip pagrindines priežastis, kodèl Lietuvoje DN atnaujinimas nèra pakankamai skatinamas, informantai ịvardija: (1) korupciją, kuri susijusi su dujų ir šilumos tiekimo įmonèmis; (2) finansavimo mažinimą; (3) būsto politikos nebuvimą ir žmonių nekompetentingumą.

Atlikto tyrimo rezultatai padèjo atskleisti, kokios priežastys stabdo gyventojų iniciatyvą atnaujinti $\mathrm{DN}$ - o tai labai reikšminga siekiant tobulinti daugiabučių namų modernizavimo politiką. Svarbu yra supaprastinti paskolų gavimo būdus, mažinti gyventojų išlaidų dalį, supaprastinti administracinius mechanizmus. Reikalingas apgalvotas motyvavimas atnaujinti iš vidaus $\mathrm{DN}$, kuriame daug pensinio amžiaus gyventojų. O kaip išjudinti $\mathrm{DN}$ atnaujinimą valstybės mastu, informantai siūlo pasiremti ir kitų šalių patirtimi. Be to, labai svarbu išspręsti korupcijos klausimus.

\section{Išvados}

1. Atlikta mokslinès literatūros analizè leidžia teigti, kad socialinis DN atnaujinimo aspektas yra labai svarbus, tačiau DN atnaujinimo apibrèžimas LT teisinèje sistemoje yra ganètinai siauras, apima išskirtinai aplinkosauginius aspektus. Ši apibrěžimą reikètų išplèsti ịtraukiant ir socialinius aspektus.

2. Mokslinejje literatūroje akcentuojama DN modernizacijos būtinybè, tačiau kol kas Lietuvoje trūksta šio reiškinio tarpdisciplininių tyrimų. Daugiausia šis reiškinys tyrinèjamas inžineriniu ir ekonominiu požiūriu, o sociologiniu požiūriu jis mažai analizuojamas.

3. DN atnaujinimas - tai sudėtingas ir aktualus fenomenas sparčiai senstančio Lietuvos gyvenamojo fondo sąlygomis. Lietuvos daugiabučių namų atnaujinimo politika, pradèta kurti dar prieš du dešimtmečius, yra nuolat papildoma, paprastinamas finansavimo modelis, tačiau mažinamas išlaidų kompensavimas. Šis nestabilumas gali riboti gyventojų iniciatyvą aktyviai įsitraukti į DN atnaujinimo procesą.

4. Valstybe ịvairiais būdais skatina/-o piliečiu iniciatyvą dalyvauti daugiabučių namų atnaujinimo procese, tačiau kol kas atnaujintų namų skaičius yra labai nedidelis. Lietuvoje iki šiol nèra DN atnaujinimo statistikos: sunku tiksliai ịvertinti mastus ir kaštus, atlikti atnaujintų namų palyginamąją analizę atliktų darbų ir išlaidų aspektais. Tokia statistika būtų reikalinga tobulinant DN atnaujinimo politiką, atliekant mokslinius tyrimus valstybejje ir tarp valstybių.

5. Kiekybinio tyrimo (anketinè apklausos) duomenų analizè parodè, kad tik nedidelè dalis namų yra renovuota pagal DN atnaujinimo programą. Dalinis DN atnaujinimas vyksta pačių gyventojų iniciatyva. Didelè dalis apklaustųjų yra patenkinti rezultatu, tačiau vardija nemažai problemų, su kuriomis susiduria ar susidūrè atnaujinant DN: gyventojų pasipriešinimas, ilgas dokumentų rengimo procesas, 
nuolat keičiama parama ir tvarka, nepasitikejimas statybos įmonėmis, sunkumai su tam tikromis gyventojų grupėmis, nepasitikèjimas bankais dèl jų griūties bei kt.

6. Atliktas interviu tyrimas parodè, jog DN modernizacija yra sudètingas ne tik ekonominis ir inžinerinis, bet kartu ir socialinis reiškinys. Kokybinio tyrimo rezultatai leido išryškinti svarbiausias su DN renovacija susijusias problemas, išskirti DN atnaujinimą skatinančius ir stabdančius veiksnius. Svarbu pabrěžti, jog Lietuvoje šilumos taupymo prioritetas neturètų būti vienintelis motyvas modernizuoti daugiabučius namus. Svarbu atsižvelgti ir ị kitus inžinerinius dalykus, praplèsti DN atnaujinimo išlaidų kompensavimo mechanizmą atsižvelgiant $\mathfrak{i}$ atskirų DN būklę, vykdyti ne pavienę, o kompleksinę modernizaciją.

7. DN atnaujinimas neabejotinai yra teigiamas reiškinys: pagerejja techninès ir energetinès namo charakteristikos, padidèja būsto verté, sumažeja importuojamų energijos šaltinių poreikis. Tačiau tiek gyventojų, tiek valdžios pastangos šị procesą tinkamai išjudinti yra per mažos, trūksta kompleksinio šio fenomeno sprendimo. Be gyventojų pasyvumo ir finansinių problemų, yra ir kitų labai svarbių masinio DN atnaujinimo kliūčių - tai valdžios korupcija, gerų statybos įmonių ir statybininkų trūkumas. Vystant ir tobulinant DN atnaujinimo politiką Lietuvoje svarbu yra pasimokyti ir iš kitų šalių patirties.

\section{Literatūra}

1. Aidukaitė J. et al. Būsto politika ir visuomenės iniciatyvos mieste. Vilnius: Lietuvos socialinių tyrimų centras. 2014.

2. Alchimoviene, J., Raslanas, S. Sustainable renovation and evaluation of blocks of multiapartment houses. Environmental engineering, The 8th International Conference. May 19-20, 2011. Vilnius: VGTU.

3. Alchimovienè J., Stasiukynas A., Gudienè N. Daugiabučių gyvenamųjų namų būklès analizè. Statyba (Civil Engineering). 2011, 3(2), 17-20.

4. Alchimovienė J. Daugiabučių namų miestų gyvenamuosiuose rajonuose darnaus atnaujinimo vertinimas. Daktaro disertacija. Vilnius: Technika, 2012.

5. Biekša D., Jaraminienè E., Martinaitis V. Daugiabučių namų renovacijos vertinimas atsižvelgiant ị trejopą naudą. Aplinkos inžinerija. 2011, 3(5), 98-104.

6. Buildings performance institute Europe (BPIE). Europe's buildings under the microscope: A country-by-country review of the energy performance of buildings. 2011.

7. Būsto energijos taupymo agentūra (BETA). „Antrasis renovacijos etapas - atjaunės dvigubai daugiau daugiabučių“. 2013-10-31. http://www.atnaujinkbusta.lt/lt/nv/ antrasis-renovacijos-etapas- [2013-11-02].

8. Cheong-Hoon, B., Sang-Hoon, P. Changes in renovation policies in the era of sustainability. Energy and Buildings. 2012, 47, 485-496.

9. Hui Xiaoxi. Housing, Urban Renewaland Socio-Spatial Integration. A Study on Rehabilitating the Former Socialistic Public Housing Areas in Beijing. Architecture and the Built Environment, 2013, Vol. 3 issue: 2. http://abe.tudelft.nl/article/view/42 [2013-08-05]. 
10. International Finance Corporation (IFC). Analysis of international best practice in organizing and financing capital repairs and energy efficiency modernizations of multi-family buildings in Central and Eastern Europe. Moscow, 2011.

11. Juozaitienė J. Daugiabučių gyvenamųjų namų padètis Lietuvoje. Konferencijos „Sąnaudos šildymui - valstybès ir vartotojų rankose“, vykusios 2007 m. lapkričio 7 d., pranešimas. Vilnius. http://www.lsta.lt/files/events/1_j.juozaitiene.ppt.pdf.

12. Leonavičius V., Genys D. Daugiabučių namų renovacija: socialinis ir ekonominis aspektai. Filosofija. Sociologija. 2014, 98-108.

13. Darni urbanistinè plètra Lietuvoje - problemos ir sprendimo būdai. Lietuvos Respublikos Seimo 2008 m. balandžio 9 d. konferencijos leidinys. Vilnius: Seimo leidykla „Valstybės žinios“, 2008.

14. Lietuvos Respublikos statybos ir urbanistikos ministro 1992 m. gegužès 20 d. ịsakymas Nr. 97 „Dèl statybos normų RSN 143-92 „Pastatų atitvarų šiluminè technika“ tvirtinimo“. Valstybės žinios. 1994, Nr. 22-367; 1995, Nr. 95-2143.

15. Lietuvos Respublikos valstybès paramos būstui įsigyti ar išsinuomoti įstatymo pavadinimo pakeitimo, 1, 2 straipsnių pakeitimo bei papildymo ir įstatymo papildymo penktuoju skirsniu įstatymas. Valstybès žinios. 2005, Nr.47-1554.

16. Lietuvos Respublikos valstybès paramos būstui ịsigyti ar išsinuomoti ir daugiabučiams namams atnaujinti (modernizuoti) įstatymo 13, 14 ir 15 straipsnių pakeitimo įstatymas. Valstybės žinios. 2013, Nr. 10-420.

17. Lietuvos Respublikos Vyriausybès 2004 m. rugsèjo 23 d. nutarimas Nr. 1213 „Dèl Daugiabučių namų modernizavimo finansavimo programos“. Valstybės žinios. 2004, Nr. 143-5232.

18. Lietuvos Respublikos Vyriausybės 2011 m. gruodžio 28 d. nutarimas Nr. 1556 „Dèl Lietuvos Respublikos Vyriausybės 2004 m. rugsėjo 23 d. nutarimo Nr. 1213 „Dèl Daugiabučių namų atnaujinimo (modernizavimo) programos ir valstybès paramos daugiabučiams namams modernizuoti teikimo ir investicijų projektų energinio efektyvumo nustatymo taisyklių patvirtinimo“ pakeitimo. Valstybès žinios. 2012, Nr. 1-1.

19. Lietuvos šilumos tiekëjų asociacija. Daugiabučių gyvenamųjų namų (DGN) atnaujinimo (modernizavimo) statistika 2014 m. spalio mèn. http://www.lsta.lt/lt/articles/ view/577?data[Filter][title]=statistika [2013-06-03]

20. Lietuvos Respublikos aplinkos ministerija. Ateities vizija - kvartalinè arba kompleksinè renovacija. 2014-01-03. http://www.am.lt/VI/article.php3?article_ $\mathrm{id}=14056$ [2014-07-16].

21. Lietuvos Respublikos aplinkos ministerija. Daugiabučių namų atnaujinimo (modernizavimo) programa - naujas modelis. http://betalt.lt/lt/apie-programa [2013-06-15].

22. Lietuvos Respublikos aplinkos ministerija. Daugiabučių namų renovacijos eiga Lietuvos savivaldybėse. renovacija.am.lt [2014-10-17].

23. Lietuvos Respublikos aplinkos ministerija. Pirmasis etapas - 840 daugiabučių. 201303-15. http://www.am.lt/VI/article.php3?article_id=12828 [2013-08-05].

24. Lietuvos Respublikos aplinkos ministerija. Renovacijos mastai - nuolat atnaujinamame žemėlapyje. 2014-06-09. http://www.am.lt/VI/article.php3?article_id=14727 [2014-07-10]. 
25. Marčènaitė R. Valstybė kratosi vedlio vaidmens ( I dalis). 2014-10-16. http://sa.lt/ valstybe-kratosi-vedlio-vaidmens/ [2014-10-17].

26. Matonienè D. Šiaulių miesto savivaldybės patirtis organizuojant daugiabučių namų atnaujinimą mieste. 2009-10-01. http://lntpa.lt/ [2013-08-20].

27. Nacionalinė žemès tarnyba prie Žemès ūkio ministerijos. Lietuvos Respublikos nekilnojamojo turto registre įregistruotų statinių apskaitos duomenys $2013 \mathrm{~m}$. sausio 1 dienai. 2013.

28. Ramanauskaitė J. Daugiabučių namų kvartalų modernizavimo strategijų analizè. Mokslas - Lietuvos ateitis $=$ Science - future of Lithuania: Statyba. 2009, 1(25), 98-102.

29. Ruseckas D., Kudlaitė A. Urbanistiniai-architektūriniai aspektai Lietuvos būsto renovacijoje. Konferencijos „Urbanistinis forumas: Lietuvos darnios erdvinès plètros sistemos kūrimas“" pranešimas. Vilnius, 2007. http://lntpa.lt/wp-content/ uploads/2012/05/Danas-Ruseckas-Urbanistiniai-architekt\%C5\%ABriniai-aspektaiLietuvos-b\%C5\%ABsto-renovacijoje.pdf [2013-04-05].

30. Stankevičius, V., Karbauskaitė, J., Burlingas, A., Šadauskienė, J., Morkvėnas, R. Expanding the possibilities of building modernization: case study of Lithuania. Journal of civil engineering and management. 2014, 20(6), 819-828.

31. Statistikos departamentas prie Lietuvos Respublikos Vyriausybès. $2011 \mathrm{~m}$. gyventojų ir būstų surašymo duomenys. http://www.osp.stat.gov.lt/web/guest/2011m.-surasymas [2013-06-28].

32. Šaparauskas J. Darnaus miesto vystymo(-si) daugiatikslè selektonovacija. Daktaro disertacija. Technologijos mokslai, statybos inžinerija - 02T. Vilnius: VGTU, 2004.

33. Thuvander, L., Femenías, P., Mjörnell, K., Meiling, P. Unveiling the process of sustainable renovation. Sustainability. 2012, 4, 1188-1213.

34. Tsenkova, S. Trends and Progress in Housing Reforms in South Eastern Europe. 2005.

35. Ustinovičius L., Ambrasas G., Alchimovienė J., Ignatavičius Č., Vilutienė T. Statinių eksploatavimas ir atnaujinimas: mokomoji knyga. Vilnius: Technika, 2012.

\title{
Anna Lipnevič
}

\section{Modernization of Apartment Buildings in Lithuania: Problems and Population's Initiative}

\begin{abstract}
Renovation of apartment houses in the academic literature is identified as one of the most important housing policy areas. This is a complex phenomenon in rapidly aging Lithuanian housing stock conditions. In the scientific literature, the need for modernization of apartment houses is emphasized, but in Lithuania, there is the lack of interdisciplinary studies of this phenomenon. Often, this phenomenon is analyzed in engineering and from an economic point of view, but from a sociological point of view, practically there have been no analyzes. The aim of the article is to reveal the apartment houses renovation policy developments in Lithuania and to highlight the most important problems of renovation.

Quantitative research data showed that only a small part of the houses is renovated under the Renovation program. Partial renovation of apartment houses is going on by themselves
\end{abstract}


according to a population initiative. A large proportion of respondents are satisfied with the results, but they listed problems in updating blocks of flats. Without passivity of the population and financial problems, there are other very significant barriers to mass renovation: corruption in government, good construction companies and builders deficiency. Qualitative research results helped to highlight the most important home renovation problems, identify renovation incentives and barriers.

Anna Lipnevič - Lietuvos socialinių tyrimų centro Sociologijos instituto jaunesnioji mokslo darbuotoja, mokslų daktarè.

E. paštas anna.lipnevic@1stc.lt

Anna Lipnevič, Junior researcher in the Institute of Sociology at Lithuanian Social Research Center.

E-mail: anna.lipnevic@1stc.1t

Straipsnis įteiktas redakcijai 2015 m. gegužès mėn.; recenzuotas; parengtas spaudai 2015 m. birželio mèn. 